\title{
Phantasms and physical imagination in Husserl's theory of pictorialization
}

REGINA-NINO MION

Estonian Academy of Arts

Faculty of Art and Culture

Institute of Art History

Estonia pst 7, 10143 Tallinn (Estonia)

reginanino@yahoo.com

Abstract: The aim of the article is to argue against the claim that Edmund Husserl does not adequately distinguish physical imagination from phantasy in his early texts. Thus, the article examines Husserl's early theory of imagination according to which phantasy and image consciousness (understood as physical imagination) have a similar structure of pictorialization but differ with respect to apprehension contents and the number of apprehended objects: phantasy involves phantasms and two apprehended objects but physical imagination involves sensations and can have three apprehended objects.

Keywords: Physical imagination, phantasy, phantasm, content-apprehension-schema, Husserl.
Resumen: El propósito del artículo es rebatir la afirmación de que Edmund Husserl no distingue adecuadamente entre imaginación física y fantasía en sus textos tempranos. Así, el artículo examina la teoría temprana de Husserl sobre la imaginación, según la cual la fantasía y la conciencia de la imagen (entendida como imaginación física) tienen una estructura similar de pictorialización, pero difieren respecto a los contenidos de la aprehensión y al número de objetos aprehendidos: la fantasía involucra fantasmas y dos objetos aprehendidos, mientras que la imaginación física involucra sensaciones y tiene tres objetos aprehendidos.

Palabras clave: Imaginación física, fantasía, fantasma, contenido-aprehensiónesquema, Husserl. 


\section{INTRODUCTION}

$\mathrm{n}$ his early writings (until 1905), ${ }^{1}$ Edmund Husserl discusses pictorialization [Verbildlichung] in the context of defining the difference between presentation [Gegenwärtigung], which describes perception, and re-presentation [Vergegenwärtigung], which characterizes memory, expectation, phantasy, and image consciousness [Bildbewusstsein]. ${ }^{2}$ Husserl believes that phantasy and image consciousness (understood as physical imagination) are examples of image presentation [Bildlichkeitsvorstellung] or imagination [Imagination] because they have the structure of pictorialization. In other words, Husserl holds the view that phantasy presentation [Phantasievorstellung] is similar to image consciousness in that in both cases we can distinguish two objects: image and subject. ${ }^{3}$ He believes that there is an appearing image that depicts the subject in physical imagination (e.g., a photograph representing a child) as well as in phantasy. More specifically, the appearing "image object" in physical imagination is analogous to the "phantasy image" in phantasy. ${ }^{4}$

However, despite these similarities, Husserl makes a clear distinction between phantasy and image consciousness. He distinguishes imaginings based on perception from imaginings belonging to phantasy. ${ }^{5}$ He even proposes various concepts to capture the uniqueness of image presentation based on perception: "physical imagination" [die physische Imagination], "physical image presen-

1. I follow the commonly held view which posits that Husserl's early theory encompasses the period from 1895/98 until 1905. The primary sources for the theory are Logical Investigations (1900-1901) and Husserliana XXIII, Phantasy, Image Consciousness, and Memory. See also J. JAnsen, Phantasy's Systematic Place in Husserl's Work: On the Condition of Possibility for a Phenomenology of Experience, in R. BERNET, D. Welton, G. Zavota (eds.), Edmund Husserl: Critical Assessments of Leading Philosophers, Vol. III (Routledge, New York/London, 2005) 221-43.

2. Cf. J. Brough, Translator's Introduction, in E. Husserl, Phantasy, Image Consciousness, and Memory (1898-1925), Collected Works, Vol. XI, trans. J. BrougH (Springer, Dordrecht, 2005) xxx (from here onwards: PhICM).

3. E. Husserl, PhICM, 22.

4. Ibidem, 20.

5. Ibidem, 47.

6. Ibidem, 20. 
tation" [die physisch-bildliche Vorstellung ${ }^{7}$ or die physische Bildvorstellung $^{8}$ ], "perceptual imagining" [die perzeptive Imagination], ${ }^{9}$ etc. These concepts might appear to be contradictory to those unfamiliar with Husserl's theory. However, it should be remembered that Husserl only wants to emphasize here the dual nature of physical imagination, that it "has a foot in both the perceptual and imaginative worlds." 10

As is well known, Husserl later abandons the idea that phantasy is a kind of imagination and has the structure of pictorialization. In his later texts, Husserl revises his theory and states that the phantasy appearance relates to its object straightforwardly and there is no phantasy image mediating in between. ${ }^{11}$ Given this, it is not surprising that philosophy papers focusing on Husserl's concept of "phantasy" have had a predominantly critical approach towards Husserl's early theory of phantasy understood as image presentation. I agree that Husserl's early theory should not be taken as the Husserlian account of phantasy. ${ }^{12}$ It is problematic to use the terminology that Husserl used in his early theory of phantasy in explaining his later theory of it without reflecting on the change of the meaning of these terms. ${ }^{13}$ However, I disagree that Husserl fails to draw a clear distinction between phantasy and image consciousness in his early texts. ${ }^{14}$ This would amount to neglecting Husserl's attempt to describe the unique experience of the "physical imagination" that is neither perception nor phantasy. As Husserl states: "Presenta-

7. Ibidem, 30 .

8. Ibidem, 47.

9. Ibidem.

10. J. BROUGH, Translator's Introduction cit., xliv.

11. E. HusSERL, PhICM, 92.

12. J. JANSEN, Phantasy's Place cit., 222. As she explains later, characteristic to the early theory is that phantasy and image consciousness are understood by Husserl as two kinds of the more general imagination [Imagination]. Ibidem, 224.

13. As Ch. FERENCZ-FLATZ points out: "Thus, the association of image-consciousness and phantasy under the same term of 'imagination' is characteristic only for Husserl's position in the Logical Investigations and this is precisely why the rendering of commentators using this term for interpreting Husserl's later statements are highly problematic", cf. C. FERENCZ-FLATZ, The Neutrality of Images and Husserlian Aesthetics, in "Studia Phaenomenologica" 9 (2009) 480.

14. J. Jansen, Phantasy's Place cit., 225. 
tions by means of phantasy images and presentations by means of physically mediated images are manifestly different kinds of experiences, never to be confused." 15 Besides, Husserl's theory of image consciousness - the experience of seeing pictures - remains basically the same from 1889 through the 1920s, with only small variations in his later texts. ${ }^{16}$ Thus, I find that Husserl's early theory of imagination and his theory of image consciousness as physical imagination both deserve a thorough study in their own right. ${ }^{17}$ In my view, as it is incorrect to maintain the parallelism between phantasy and image consciousness in discussing Husserl's later account of phantasy, it is likewise incorrect to explain Husserl's early theory of image consciousness without distinguishing it from phantasy, or to examine it on the basis of how well it explains the experience of phantasy alone.

The aim of this article is to emphasize the uniqueness of physical imagination, and to show how it differentiates from both phantasy and perception in Husserl's early writings. To this end, I will focus on Husserl's content-apprehension-schema, which plays an essential role in understanding his early theory of pictorialization. I will show that it is a mistake to claim that phantasms, which function as the contents for the "phantasy image" apprehension, are involved in physical imagination, as well as that there are only two apprehensions involved in physical imagination. In what follows, I will first give an overview of the content-apprehension-schema and the concept of "phantasm" in Husserl's early writings. Secondly, I will discuss the similarities and differences between phantasy and physical imagination, both taken as examples of pictorialization. I will show that there are two apprehensions needed for pictorialization to occur, but physical imagination, as a unique kind of pictorialization, involves one more-three apprehensions in total. I will also comment on some Husserl interpreters who claim that phantasms are involved in physical imagination. Moreover, I will show that

\section{E. HusSERL, PhICM cit., 131.}

16. J. BROUGH, Translator's Introduction cit., xliv.

17. An important contribution has been made by John Brough. See one of his wellquoted articles: J. Brough, Some Husserlian Comments on Depiction and Art, in "American Catholic Philosophical Quarterly" LXVI/2 (1992) 241-59. 
phantasms are not the apprehension contents for the constitution of subject, not even in phantasy. Lastly, I will point out some further details that contribute to the understanding of the uniqueness of physical imagination.

\section{WHAT ARE PHANTASMS?}

Husserl discusses the concept of "phantasm" in relation to the content-apprehension-schema [Inhalt-Auffassung-Schema]. ${ }^{18}$ The schema is based on Husserl's theory about the different modes of the relation of consciousness to its object. It is best explained in Logical Investigations, in which Husserl states that every representation includes three parts: 1) the form of apprebension [Auffassungsform], which defines whether the object is presented in purely signitive [signitiv], intuitive, or mixed fashion; 2) the matter of apprehension [Auffassungsmaterie], which defines whether the object is presented in this or that "sense"; 3) the apprebended contents [aufgefaßten Inbalte]. ${ }^{19}$ Since contents are non-intentional by themselves and do not refer to anything until they are interpreted, "the content wins its intentional relation to something objective only through an interpreting apprehension." ${ }^{20}$

Husserl calls the content of perceptual presentation the "sensation" [Empfindung] and that of phantasy presentation the "phan-

18. E. Husserl, PhICM cit., 323. It has also been called the matter-form schema. See R. SOKOLOWSKI, The Formation of Husserl's Concept of Constitution (Martinus Nijhoff, The Hague, 1970) 105.

19. R. D. RollingeR, Husserl and Brentano on Imagination, in „Archiv Für Geschichte Der Philosophie" 75 (1993) 204. Although Husserl adds to the definition of the form of apprehension that "Here also belong the differences between a perceptual and an imaginative presentation" [Cf. E. HussERL, Logical Investigations., D. MoRAN (ed.), vol. 2 (Routledge, New York/London, 2001) 245], he only wants to say that it is not the matter of apprehension that gives the difference between the two. When it comes to defining the difference between perception and phantasy, he is primarily interested, however, in the content. In other words, he is concerned with whether the content of perceptual presentation (sensation) and the content of the phantasy presentation (phantasm) exhibit some intrinsic difference independently of the form of apprehension (cf. R. D. RoLLINGER, Husserl and Brentano on Imagination cit., 205).

20. J. Brough, Translator's Introduction cit., lvii. 
tasm" [Phantasma]. ${ }^{21}$ In Husserl's view, the difference between phantasy and perception is neither in the degree of intensity of the content, as Brentano claimed, nor is it in the object, since the phantasy presentation and the object of the perceptual presentation can be identical. ${ }^{22}$ Although Husserl believes that "[p]hantasms, too, are sense contents [Sinnesinbalte], and sense contents of the same genus and species as those to be found in sensation [Empfindung], ${ }^{23}$ the contents of phantasy acts, however, are not sensations [Empfindungen] since in phantasy there is no actual physical object from which one can have sensations. The phantasy object is not perceived, it is absent.

It is generally well known that the distinction between sensations and phantasms concerns the distinction between perception and phantasy. Husserl refers to this in many of his manuscripts. For instance, in Husserliana $\mathrm{X}$ he writes that "We therefore distinguish perceptual appearances and phantasy-appearances. The latter contain "phantasms" (re-presentational modifications of sensations) as their apprehension-material; the former contain sensations." 24 What is less known, or less noticed, is that the distinction between sensations and phantasms also applies to the distinction between imaginings based on perception (physical imagination) and imaginings belonging to phantasy. ${ }^{25}$ Hence, the aim of my article is to draw attention to these differences.

Before I come to the analysis of phantasms and physical imagination, I would like to note that Husserl had already begun to express doubts about the efficacy of the content-apprehensionschema around $1905 .{ }^{26}$ One of the reasons for the eventual aban-

21. E. Husserl, PhICM cit., 11.

22. R. D. Rollinger, Husserl and Brentano on Imagination cit., $199 f$.

23. E. HuSSERL, PhICM cit., 81.

24. E. HusserL, On the Phenomenology of the Consciousness of Internal Time (1893-1917) (Kluwer Academic Publishers, Dordrecht, 1991) 108.

25. E. HusserL, PhICM cit., 47.

26. Probably the most famous statement of it is from 1909: "I had the schema 'content of apprehension and apprehension,' and certainly this schema makes good sense. However, in the case of perception understood as a concrete experience, we do not first of all have a color as content of apprehension and then the characteristic of apprehension that produces the appearance. And likewise in the case 
doning of the schema is that Husserl had difficulties defining phantasms. As Brough explains, Husserl cannot clarify the distinction between sensations and phantasms, and neither can he solve the question whether phantasms are present or absent. ${ }^{27}$ According to Brough, on the one hand Husserl claims that there is nothing "present" in phantasy. However, on the other hand, since phantasms and apprehensions serve as representants for what is not present (the phantasy object), they must necessarily be present, for Husserl believes that something absent or non-present can be represented only by something present. ${ }^{28}$ Multiple problems arise from said contradictions. For instance, how is it that (present) phantasm "undergoes apperception into something that is not there itself"? 29 Moreover, how can there be any present contents in consciousness in the first place? ${ }^{30}$ After a long struggle with the questions, Husserl finally comes to the understanding that the real problem lies in the content-apprehension-schema itself. However, the contentapprehension-schema still plays an essential role in explaining the

of phantasy we do not again have a color as content of apprehension and then a changed apprehension, the apprehension that produces the phantasy appearance. On the contrary: 'Consciousness' consists of consciousness through and through, and the sensation as well as the phantasm is already 'consciousness."' Ibidem, 323.

27. J. BROUGH, Translator's Introduction cit., lix-lx.

28. Brough calls this the "prejudice of presence" according to which "one can be aware of what is absent only through something present" (J. BROUGH, Translator's Introduction cit., liii.) That is why the content-apprehension-schema is also called an empiricistically influenced theory of consciousness: "This theory assumes present, experienced contents - sensations and phantasms-within consciousness (however they may have arisen)". R. BERnET, I. KERn, E. MARBACH, An Introduction to Husserlian Phenomenology (Northwestern University Press, Chicago, 1993) 260. Later, Husserl changed the view and claimed that the consciousness of what is absent "does not depend on the actual presence of some content or image in consciousness" (cf. J. BROUGH, Translator's Introduction cit., liv.) Thus, even an absent object (in memory, phantasy) can be intended directly.

29. E. Husserl, PhICM cit., 201. "Are phantasms contents that appear as present? A peculiar question. Can they appear as present? If what is phantasied does not appear as present, does not the phantasm likewise appear as nonpresent?," Ibidem, 201.

30. This is related, as Jansen points out, to the analysis of internal time consciousness and the idea of absolute consciousness: "It is impossible for an absolute, a-temporal consciousness to 'contain' present sensations or phantasms", cf. J. JANSEN, Phantasy's Place cit., 228. 
constitution of the image consciousness as physical imagination and the early theory of phantasy, as will be explained below.

\section{Phantasy AND Physical imagination: PiCtORIALIZATION}

In his Göttingen period, Husserl gave a lecture course entitled "Principal Parts of the Phenomenology and Theory of Knowledge" (in 1904/05). As J. N. Mohanty summarizes, the course had four parts: i) perception; ii) attention and specific intendings [Meinen]; iii) phantasy and picture consciousness [Bildbewusstsein]; and iv) phenomenology of time. ${ }^{31}$ The third part of the course is (largely) published in Text $\mathrm{N}^{o} 1$ in Husserliana XXIII, Phantasy, Image Consciousness, and Memory, ${ }^{32}$ and here Husserl ponders the possibility that phantasy is a kind of pictorialization [Verbildlichung], an idea that Husserl finds doubtful already by the end of the lecture course. ${ }^{33}$ However, the idea is fascinating and reveals some of the important moments in the development of Husserl's philosophy.

Thus, in his early theory Husserl believes that phantasy is distinguished from perception in that the object of phantasy appears to us in image and does not appear as present itself, like the object of perception does. ${ }^{34}$ To quote Husserl: "Anyone who phantasies has an image experience. Something objective appears to him. However, no one considers this appearance to be an appearance

31. J. N. Mohanty, The Development of Husserl's Thought, in B. SMith, D. W. SMith (eds.), The Cambridge Companion to Husserl (Cambridge University Press, Cambridge, 1995) 57.

32. The first two parts are published in Husserliana XXXVIII, Wabrnebmung und Aufmerksamkeit, and the fourth part in Husserliana X, Zur Phänomenologie des inneren Zeitbewusstseins [On the Phenomenology of the Consciousness of Internal Time].

33. In a footnote of the $\$ 8$ entitled "Phantasy presentation as pictorialization. Beginning the process of defining the essence of image presenting", Husserl writes: "We intend to try to pursue as far as possible the point of view of imagination and the notion that phantasy presentation [Phantasievorstellung] can be interpreted as image presentation [Bildlichkeitsvorstellung] —although there is no dearth of objections to this attempt, objections that subsequently turn out to be justified." Cf. E. HusSERL, PhICM cit., 18.

34. Ibidem. 
of the object itself." ${ }^{35}$ Now, the re-presenting in image involves image and subject: the image presents the subject and the subject is what is meant by the presentation. ${ }^{36}$ This experience, however, is an image consciousness: "what resembles something turns into an image of it only through the unique and absolutely primitive image consciousness." ${ }_{37}$ The term "image consciousness" [Bildbewusstsein or Bildlichkeitsbewusstsein] is often translated into English as "picture consciousness" 38 or "pictorial consciousness." 39 The reason is probably that the term image consciousness is consistently used by Husserl to describe what he calls "physical imagination" [die physische Imagination], and only occasionally used to describe phantasy (in his early theory). According to Husserl, physical imagination comes into play every time we look at a picture that has a physical basis, like a photograph, a painting, a drawing, but also film and other moving pictures. Therefore, the terms "image consciousness" and "physical imagination" are often used synonymously. ${ }^{40}$ However, in Husserl's early theory, both physical imagination and phantasy presentation are examples of pictorialization that are experienced through image consciousness.

Physical imagination involves three objects: i) the physical image [das physische Bild] or the physical thing [Bildding] —a thing made from canvas, paper or some other materials (e.g., a painting called "Emperor Maximilian"); ii) the image object [Bildobjekt]—the representing or depicting image, also the appearing image (i.e., the image of the Emperor); and iii) the image subject [Bildsujet]-the

35. Ibidem, 27.

36. Ibidem, 19-20.

37. Ibidem, 18.

38. Cf. J. N. Mohanty, The Development of Husserl's Thought; P. SHUM, The Evolution and Implications of Husserl's Account of the Imagination, "Husserl Studies" 31/3 (2015) 213-236; J. Jansen, Phantasy's Systematic Place cit.

39. Cf. R. Bernet, Unconscious Consciousness in Husserl and Freud, in D. Welton (ed.), The New Husserl: A Critical Reader (Indiana University Press, Bloomington, 2003) 199-219.

40. For instance, John Brough, the English translator of Husserliana XXIII, explains the threefold physical imagination in the section "Image Consciousness" (cf. J. BROUGH, Translator's Introduction cit., xliv-li). 
represented or depicted object (i.e., the Emperor). ${ }^{41}$ Phantasy, understood as pictorialization, involves two objects: i) the phantasy image [das Phantasiebild], and ii) the image subject [Bildsujet]. ${ }^{42}$ Thus, as Husserl summarizes, "Three objectivities were interwoven in physical imaging; two were interwoven in phantasy." ${ }^{43}$

Husserl believes that physical imagination and phantasy presentation are parallel cases of pictorialization since both involve image (he takes the image object [Bildobjekt] to be the analogue of the phantasy image $[\text { das Phantasiebild }]^{44}$ ), and subject (the image subject [Bildsujet]). They differ with respect to the physical thing. As Husserl explains, the physical thing, as a real object, belongs to perception's field of regard and functions as the instigator of the pictorial apprehension in the case of physical imagination; but "phantasy presentation has no instigator" 45 and it means that the phantasy image is not tied to any physical excitant. ${ }^{46}$

Another difference between physical imagination and phantasy is in the apprehension contents: sensations are involved in physical imagination and phantasms in phantasy. Since no physical instigator is involved in phantasy, the phantasy image is apprehended only on the basis of phantasms. ${ }^{47}$ To quote Husserl:

As far as the act-characteristics are concerned, the phantasy image and the physically presented image are internally of the same sort: There are certainly pictorial re-presentations in both cases. They differ, however, through their presenting sensuous contents. On one side, there are phantasms; on the other, sensations. ${ }^{48}$

41. E. Husserl, PhICM cit., 21.

42. Ibidem, 25.

43. Ibidem, 30.

44. Ibidem, 20.

45. Ibidem, 135.

46. Ibidem, 22.

47. Ibidem, 23.

48. Ibidem, 136. 
In fact, the physical image (or the physical thing) and the image object apprehensions use the same sensuous contents, that is, the contents are identical: "The same visual sensations are interpreted as points and lines on paper and as appearing plastic form." ${ }^{49}$ There is a clear dependence of the image object apprehension on the physical thing perception: we have the sensuous contents to be apprehended as the image object by perceiving the physical thing that exists in the physical world. ${ }^{50}$ Therefore, it is absolutely correct to say that in the absence of the physical thing, "there would be no image consciousness at all," ${ }_{51}$ if by image consciousness we mean the physical imagination.

Still, the clear dependence on the physical instigator has led some Husserl interpreters to question the parallelism between physical imagination (or image/picture consciousness) and phantasy. For example, Julia Jansen notes that the image object needs the physical image as the carrier of its sensual content, but in phantasy, "there is no such carrier to be distinguished from the phantasy appearance itself." ${ }^{52}$ Moreover, we cannot say that phantasmatic contents are experienced the same way sensations are. ${ }^{53}$ Also, Peter Shum criticizes Husserl's early understanding of phantasy in that it leaves out the "picture-thing." Shum refers to Husserl's claim that one must be able to switch attention back and forth between image-object and picture-thing, and if so, then "the possibility in principle of turning one's attention to the picture-thing is an essential part of

49. Ibidem, 48. See also: "The same sensations are interpreted as a physical thing made from plaster and as a white buman form." cf. Ibidem.

50. Husserl believes that the image object, as well as the phantasy image, do not truly exist. What exist instead are the physical thing and the "complex of sensations," cf. E. HusSERL, PhICM cit., 23.

51. J. BROUGH, Translator's Introduction cit., xlv.

52. J. Jansen, Phantasy's Systematic Place cit., 225.

53. Jansen is referring here to the same problem with the content-apprehensionschema that was mentioned before, namely that how can something present be apprehended as something absent. To quote Jansen: "Further, it is problematic to assume that phantasmatic contents are present to us in the same way as sensations. If they were, it would be difficult to see how phantasmatic contents could ever be apprehended as something that is not present, that is precisely absent, namely the phantasized presentified object." Ibidem. 
the structure of picture-consciousness itself." ${ }^{54}$ Shum arrives at the following conclusion:

If the hypothesis that phantasy has the structure of pictureconsciousness is true, then imagining, say, a landscape, implies the necessary possibility of turning one's attention towards a picture-thing bearing the landscape's image. The picture-thing itself must therefore be capable in principle of being constituted in phantasy. It would seem that we are then obliged to permit the possibility in principle of turning one's attention towards a new picture-thing bearing the first picture-thing's image. But then we would be faced with an infinite regress. The hypothesis that phantasy has the structure of picture-consciousness is therefore showing itself to be deeply problematic. ${ }^{55}$

I would like to answer to the criticism by showing that even in the absence of the physical carrier, phantasy can still be considered an example of pictorialization according to Husserl. To explain this, a deeper look at the Husserl's manuscripts is needed. In Chapter 2 in Text $\mathrm{N}^{\circ} 1$ in Husserliana XXIII, Husserl first claims that phantasy presentation is pictorialization because the object in phantasy appears to us in image. ${ }^{56} \mathrm{He}$ then specifies what the re-presenting in image means and claims that we need to be able to distinguish image and subject in it. Next, he claims (in \$9) that physical imagination is a parallel case to phantasy presentation precisely because we can also distinguish image and subject in it. The only difference is that the concept of "image" is a double concept in the case of physical imagination. To quote Husserl:

When we distinguish between subject and image in this case [physical imagination], we immediately note that the concept of the image is a double concept. That is to say, what stands

54. P. SHum, The Evolution, op. cit., 222.

55. Ibidem.

56. E. Husserl, PhICM cit., 18. 
over against the depicted subject is twofold: 1) The image as physical thing, as this painted and framed canvas, as this imprinted paper, and so on. In this sense we say that the image is warped, torn, or hangs on the wall, etc. 2) The image as the image object appearing in such and such a way through its determinate coloration and form. ${ }^{57}$

Thus, Husserl suggests in these paragraphs that the essential elements of pictorialization are image and subject, and that the image as a physical thing is not essential for pictorialization to occur. Husserl clearly states that "In the case of physical imagination, a physical object that exercises the function of awakening a 'mental image' is presupposed; in phantasy presentation in the ordinary sense, a mental image is there without being tied to such a physical excitant. In both cases, however, the mental image is precisely an image; it represents a subject." ${ }^{28}$ This does not, of course, dispute the claim that the physical image is an essential element in image consciousness as physical imagination. It does, however, say that phantasy presentation without involving physical things is still pictorialization.

\section{Phantasms and Physical imagination}

As explained in the last section, pictorialization involves image and subject, and the contents for the apprehension of image(s) are either sensations (physical imagination) or phantasms (phantasy). It was also noted that phantasms are not involved in the constitution of the two images in case of physical imagination. Now, what about subject? Can we say that there must be some apprehension contents

57. Ibidem, 20. The same idea is repeated in the Appendix I for Text No 1 (pp. 117118).

58. Ibidem, 22. In fact, some interpreters note that it is not the "physical thing" that is problematic in phantasy, but rather the "phantasy image", that is, to find the counterpart to the "image object" in phantasy. For instance, it has been claimed that Husserl later "distinguishes phantasy from picture-consciousness precisely by the lack of a counterpart to the picture-object in phantasy" (cf. J. JANSEN, Phantasy's Systematic Place, op. cit., 226.), or to put it differently, that the distinction between image and subject collapse (J. BROUGH, Translator's Introduction cit., liv.) 
functioning for the apprehension of the subject? And if so, are these sensations or phantasms?

The contents of phantasy acts are not sensations since in phantasy there is no physical thing from which one can get sensations. A painting, for example, is a physical object that is present and perceived, but we also see something in the painting that is not physically present, but absent. One might think that, in this case, we have both sensations and phantasms. This is suggested by Rudolf Bernet:

Translated into the terminology of Husserl's early analysis of perception, this means that in pictorial consciousness there are two apprehensions, one based on the other, the first of which is supported by sensations and brings the pictorial image to appearance while the other animates mere "phantasms" and thereby explains the givenness of the pictorial subject depicted in the pictorial object. ${ }^{59}$

A similar claim is made by Andreea Smaranda Aldea, who believes that phantasms must be involved in the second apprehension of image consciousness. To quote Aldea:

Furthermore, unlike the foundational apprehension of the Bildding through which the appearance of the image object is facilitated, the apprehension of the image object as that through which the sujet is presented is a modifying apprehension. [...] The sujet is given as irreal through and through. [...] And unlike the first foundational perceptual apprehension, which has sensation as its content, the second, modifying apprehension of image consciousness has phantasma as content. Phantasmata, according to Husserl, are the contents of apprehensions that bring forth non-presence as irreality. ${ }^{60}$

59. R. BERNET, Unconscious Consciousness in Husserl and Freud cit., 203.

60. A. S. AldEA, Husserl's Struggle with Mental Images: Imaging and Imagining Reconsidered, in "Continental Philosophy Review" 46/3 (2013) 378. 
It is unfortunate that neither Bernet nor Aldea provide any reference to Husserl's text that would support their claims about phantasms being involved in the objectivation of the subject. What they say, however, is incorrect. It is not true, I would argue, that there are only two apprehensions in image consciousness according to Husserl's early theory. Nor is it true that phantasms are involved in the apprehension of subject. In what follows I aim to show three things: i) there are altogether three apprehensions in physical imagination, ii) the apprehension of the subject is not based on any apprehension contents, and iii) phantasms are not involved in the constitution of subject, even in the case of phantasy.

To begin with, Husserl refers to the "two apprehensions" only when he describes phantasy presentation, e.g., $\$ 11$ "The relation to the image subject, or the two apprehensions, one built on the other, in phantasy presentation [...],"61 or when he wants to point out the similarities between various kinds of imagination, e.g., $\$ 13$ "The two apprehensions belonging essentially to the constitution of imaginative presentation." ${ }^{2}$ As I mentioned before, two essential apprehensions or two essential objectivities of pictorialization (understood as "imagination" in his early theory) are image and subject. These two objectivities, image and subject, are necessarily involved in every kind of imagination, or in other words, the necessary occurrence of image and subject is what physical imagination and phantasy presentation have in common. Now, as I also explained above, physical imagination is a special case of pictorialization, as the image is a double concept-instead of one image we experience two. ${ }^{63}$ These, the physical thing [Bildding] and the image object [Bildobjekt], are apprehended separately. Accordingly, since there are in total three objectivations involved in physical imagination (Bildding, Bildobjekt and Bildsujet), there must also be three apprehensions involved in it. ${ }^{64}$ As John Brough summarizes Husserl's theory:

61. E. HuSSERL, PhIC cit., 24.

62. Ibidem, 28.

63. Ibidem, 20.

64. Husserl often refers to "objectivation" and "apprehension" equivalently. For instance: "In order to make two objects present, however, two objectivations, two 
Finally, image consciousness involves not one, but as many as three apprehensions. [...] These three distinct but inseparable apprehensions mutually achieve the constitution of the three entwined objects of the unitary depictive act. ${ }^{65}$

There are different interpretations of what are the (necessary) "two apprehensions" referred to by Husserl in his early theory of pictorialization. For example, Andreea Smaranda Aldea writes in her article that the structure of image consciousness [Bildbewusstsein] involves three objects: Bildding, Bildobjet and Bildsujet; and then she adds: "This would suggest three corresponding apprehensions for each of these objects, but Husserl discusses the structure of Bildbewusstsein in terms of two apprehensions: one pertaining to the Bildding and the other to the Bildobjekt-Bildsujet structural complex." 66 It is unclear why she denies the fact that there are three apprehensions that correspond to the three objects in image consciousness. But she also errs in suggesting how the necessary two apprehensions of imagination are divided.$^{67}$ In this light, Rudolf Bernet's reading of Husserl's early theory is correct with respect to the division of the "two apprehensions." In the quotation given above, he claims that one apprehension corresponds to image ("pictorial image") and the other to subject ("pictorial subject"). ${ }^{68} \mathrm{He}$ only errs in leaving out the physical thing's apprehension and in saying that these are phantasms that are animated for the apprehension of the subject.

Husserl believes that the physical thing apprehension and the image object apprehension use the same apprehension contents. ${ }^{69}$

apprehensions, are needed." Ibidem, 22.

65. J. BROUGH, Translator's Introduction cit. lix.

66. A. S. AldEA, Husserl's Struggle with Mental Images, op. cit., 374.

67. A few pages later, she claims that "The Bildding and Bildobjekt are given in one apprehension - the former is perceptual, the latter marked by irreality." Unfortunately, this is not a correct interpretation either, and it also contradicts what she previously claimed.

68. R. BeRnet, Unconscious Consciousness in Husserl and Freud cit., 203.

69. This might explain why Aldea thinks that Bildding and Bilobject are given in one apprehension (see the comment above). 
And Husserl explicitly states that the same apprehension contents give two separate apprehensions. To quote him:

The image object and the physical image surely do not have separate and different apprehension contents; on the contrary, their contents are identically the same. The same visual sensations are interpreted as points and lines on paper and as appearing plastic form. The same sensations are interpreted as a physical thing made from plaster and as a white buman form. And in spite of the identity of their sensory foundation, the two apprehensions certainly cannot exist at once: they cannot make two appearances stand out simultaneously. By turns, indeed, and therefore separately, but certainly not at once. ${ }^{70}$

Husserl believes that the image subject is intended in a singular way. However, it does not have an appearance of its own; there is no second appearance in addition to the image (image object) appearance. This is because there are no contents left which could be apprehended as a new presentation or appearance. More precisely, Husserl claims that there are no apprehension contents left for the subject because all available contents are already used up in the constitution of the image object. To quote him: "The new apprehension is not a new presentation: From where is it supposed to take its apprehension contents? All of the sensuous contents available have already been used up in the constitution of the image object."71 What happens is that the subject apprehension is founded in the apprehension belonging to the image object. Husserl explains this in the following way:

We have only one appearance, the appearance belonging to the image object. But we have more than the one apprehension (or, if you wish, the one objectivation) in which this image object

70. E. HuSSERL, PhICM cit., 48-49.

71. Ibidem, 28. 
becomes constituted for us. If this were not the case, nothing else but the image object could be meant. In the image object we image the subject, which is more or less different from-even if resembling-the image object: A second objectivating characteristic [objektivierender Charakter] is there, a new apprehension with a new apprehension sense that is founded in the apprehension belonging to the image object, and it is precisely this that brings about for consciousness what we express when we say: "With the appearing image we mean the subject." 72

And he adds:

Phenomenologically, however, it is inherent in this that the image object does not merely appear but bears a new apprehension-characteristic [Auffassungscharakter], which is permeated and fused in a certain way with the original [and] which, as it were, refers to the object properly meant not simply at a distance from the content of what appears, but in it, or refers to the object properly meant through this content. ${ }^{73}$

In other words, the two objectivating apprebensions [objektivierende Auffassungen] — the image object and the image subject-are interwoven with one another, so that the intuition of the image object awakens a presentation of a new object (subject) which has an internal affinity with, or resemblance to, the image object. ${ }^{74}$ Husserl also calls the apprehension of the image object the direct objective apprehension [direkte gegenständliche Auffassung] and that of the image subject the indirect apprehension [indirekte Auffassung]. ${ }^{75}$

What is important at this juncture is that there are no separate contents - neither sensations nor phantasms - available for the appearance of the subject. The subject in physical imagination

72. Ibidem, 31 .

73. Ibidem.

74. Ibidem, 32.

75. Ibidem, 34 . 
is apprehended, but nowhere is Husserl saying that the apprehension of the subject animates sensuous contents, let alone phantasms. In fact, not even in the case of phantasy are phantasms involved in the apprehension of the subject. In Appendix I for Text $\mathrm{N}^{\circ} 1$, Husserl describes how the subject is given in the case of phantasy presentation:

The new apprehension, however, is not a new presentation. From where is it to get its presentative contents? All of the phantasms (as we simply call the sensuous, experienced contents of phantasy) are fully consumed in the presentation of the image. [...] Thus the new apprehension, instead of objectivating new sensuous contents, can only make the first apprehension into the foundation of a new objectivation. ${ }^{76}$

To some extent it is understandable why it is believed that phantasms are the apprehension contents for subject because it seems obvious that sensations cannot be the apprehension contents for the absent image subject in physical imagination. Moreover, we find texts in which Husserl writes that "imaginational apprehensions [...] belong to phantasms"; ${ }^{77}$ and he even ponders the possibility of mixed experience. He writes: "Furthermore, there is no doubt that we can experience sensations and phantasms at the same time, as when, for example, we read notes and accompany our reading with tone phantasms, or when we phantasy a melody while attending to our visual perceptions, and so on." ${ }^{78}$ However, phantasms are apprehension contents for the phantasy image to appear in phantasy-not for objects in physically mediated images. A clear distinction is made

76. Ibidem, 124. "Die neue Auffassung ist aber keine neue Präsentation. Wo sollte sie auch den präsentativen Inhalt hernehmen? Alle Phantasmen (so nennen wir kurzweg die sinnlichen, erlebten Inhalte der Phantasie) sind zur Präsentation des Bildes voll aufgebraucht; [...] So kann die neue Auffassung, statt neue sinnliche Inhalte zu objektivieren, nur die erste Auffassung zum Fundament einer neuen Objektivierung Machen.”, cf. E. HusserL, Phantasie, Bildbewusstsein, Erinnerung, Husserliana XXIII, E. MARbaCH (ed.) (Martinus Nijhoff, The Hague, 1980) 114.

77. E. Husserl, PhICM cit., 85.

78. Ibidem, 81. 
by Husserl: "The apprehension of experienced sensuous contentsof sensations in the case of the contemplation of a physical image, of phantasms in the case of phantasy imaging-yields the appearing image, the appearing representing image object" [my italics]. ${ }^{79}$ The distinction is also mentioned by Eduard Marbach in the editor's introduction to Husserliana XXIII. ${ }^{80}$

\section{CONCLUDING REMARKS}

The aim of this article was to defend the uniqueness of the experience of "physical imagination." I have claimed that physical imagination is distinguished from phantasy with respect to the apprehension contents, as well as to the number of objectivations or apprehensions involved therein. More precisely, I have shown that although physical imagination is a kind of imagination, there are no phantasms involved in the constitution of its "objects," and because of the double concept of image, there are more apprehensions involved in physical imagination than in phantasy. However, there are further details concerning the difference between the two. For instance, Husserl states that in the case of imagining presentations, several essentially different apprehensions are based on one another [aufeinander] or in one another [ineinander]. ${ }^{81}$ In this way he is referring to the idea that phantasy presentation is analogous to symbolizing, ${ }^{82}$ and as such "we have two apprehensions, one built on the other." 83 But pictorial presentations differ from symbolic presentations in that the pictorial presentations point to an object

79. Ibidem, 24. See also Appendix I for Text $\mathrm{N}^{\circ} 1$ in which Husserl states that phantasy presentation and physical image presentation emerge "from a differently constructed apprehensional basis." Ibidem, 135.

80. "Und als möglichen inneren Unterschied der beiden Arten bildlicher Repräsentation bringt er „die präsentierenden sinnlichen Inhalte”, Empfindungen bei den gewöhnlichen Bildvorstellungen, Phantasmen bei den Phantasievorstellungen, in Anschlag (S. 124).", cf. E. MARBACH, Einleitung des Herausgebers, in Phantasie, Bildbewusstsein, Erinnerung (Martinus Nijhoff Publishers, The Hague-BostonLondon, 1980) lvi.

81. E. Husserl, PhICM cit., 30.

82. Ibidem, 26.

83. Ibidem, 25. 
through itself, and thus we are "supposed to immerse ourselves in the image" [in das Bild bineinschauen]. ${ }^{84}$

Finally, I would like to draw attention to the fact that Husserl not only has difficulties in defining phantasms in the contentapprehension-schema-whether they are present or absent-but he also notes that sensations may not help distinguish perception from physical imagination, for the same sensation contents function as the apprehension contents for both experiences. In my view, this shows that the problems with the content-apprehension-schema are not only related to the concept of "phantasm," but also to "sensation." Because of the perception of the "physical thing" that serves as the basis for physical imagination, Husserl expresses no doubts about the presence of sensations, and yet pictures show absent things. Thus, the important question is why the apprehension contents in physical imagination do not give us a mere perceptual apprebension, but instead the apprehension has the characteristic of representation by means of resemblance. ${ }^{85}$ In other words, why does not the picture (the painting, the photograph) "deceive" us, although, as Husserl clearly states that "the presenting contents are not generically distinguished from those of perception and consequently the corresponding appearances do not show any kind of essential differences either." 86 Husserl adds: "It is precisely in this respect that the study of ordinary image presentations, sadly neglected up to now, proves to be extremely instructive. For the image here is the 'objectification' of sense contents, and yet this objectification is not a perceptual presentation." ${ }^{87}$ Hence the peculiarity and uniqueness of physical imagination, and the need for further study of the experience. $^{88}$

84. Ibidem, 37.

85. Ibidem, 28.

86. Ibidem, 148.

87. Ibidem, 121. See also "In the imaginative presentation occurring in the contemplation of a painting, we certainly do have sensations as contents of apprehension. The result of the apprehension, however, is not a perception", Ibidem, 27.

88. This work was funded by the European Regional Development Fund and the programme Mobilitas Pluss no. MOBJD203. 
